The Polish Journal of the Arts and Culture. New Series 10

(2/2019): 153-169 [ARTYKUE]

DOI: $10.4467 / 24506249$ PJ.19.016.11988

\title{
Melancholia jako doświadczenie straty. Literaturoznawcze studium przypadku Filipa Verheyena z Biegunów Olgi Tokarczuk
}

\section{Karolina WyciśLIK}

\begin{abstract}
Streszczenie
Praca ta stanowi propozycję lektury fragmentu książki Olgi Tokarczuk w perspektywie doświadczenia melancholicznego i ma celu ukazanie rysu melancholicznego wybranego bohatera Biegunów. Autorka, posługując się narzędziami interpretacyjnymi z zakresu literaturoznawstwa, tworzy swoiste case study: analizuje tekst literacki i wskazuje na tropy melancholijne, które pojawiają się w całej twórczości autorki Ksiag fakubowych. Postać flandryjskiego naukowca Filipa Verheyena badana jest w aspekcie natury ludzkiej oraz ciała, które „odpowiada” na cierpienie psychiczne.
\end{abstract}

Słowa kluczowe: Tokarczuk, melancholia, strata, ból

Karolina WycıśLıK doktorantka w Szkole Doktorskiej Uniwersytetu Śląskiego w dziedzinie literaturoznawstwa, jej zainteresowania badawcze obejmują prozę współczesną oraz związki muzyki i literatury - w szczególności poezji dwudziestowiecznej - w perspektywie ekologii akustycznej.

E-MAIL: karolina.wycislik@us.edu.pl 


\section{Wstęp}

Pojęcie melancholii w kulturze europejskiej obecne jest od antyku (Klibansky, Panofsky i Saxl 2009, 5). Jak wskazał jednak Jean Starobinski, stanu tego ludzkość doświadczała „na długo, zanim otrzymała [melancholia - K.W.] swą nazwę i medyczne wyjaśnienie" (Starobinski 2017, 17). Już wówczas nieudolnymi stawały się próby dążące do wyjaśnienia, z jakiego powodu człowiek obarczony melancholią popadał w niełaskę bogów ${ }^{1}$. Słusznie zauważyli Raymond Klibansky, Erwin Panofsky i Fritz Saxal, że niewiele jest kategorii pojęciowych w historii myśli Zachodu tak niejednoznacznych, jak melancholia (Klibansky, Panofsky i Saxl 2009, 5). Uciążliwy temperament, choroba psychiczna, doświadczenie filozoficzne, źródło rozkoszy - przez lata termin ewoluował, choć - na co zwracają uwagę autorzy Saturna i melancholii - „nowe znaczenia nie wypierały starych” (Klibansky, Panofsky i Saxl 2009, 25). $\mathrm{W}$ efekcie od V wieku p.n.e. posługujemy się tym samym słownictwem na określenie różnorodnych zjawisk ${ }^{2}$.

1 Jean Starobinski tłumaczy, powołując się na pieśń VI Iliady, że w świecie Homera aktywność ludzka, polegająca na kontakcie z drugim człowiekiem, musi zyskać akceptację bogów. W przeciwnym wypadku istota ludzka będzie przeżywać stany depresyjne, dojmujący smutek spowodowany samotnością. Stany te autor łączy z pojęciem „melancholii” (Starobinski 2017).

${ }^{2}$ Hipokrates określił melancholię jako chorobę psychiczną, doszukując się jej źródeł w zmieszanych w odpowiednich proporcjach substancjach biologicznych - z przewagą czarnej żółci. One z kolei miały odpowiadać ciałom niebieskim i okresom kosmicznym, które wpływały na ludzkie życie. Z szaleństwem twórczym związał melancholię Arystoteles, przekonując, że wybitne jednostki cechują się melancholicznym temperamentem. W okresie średniowiecza pojęcie to łączono z chorobą, rozumianą także poprzez aspekt psychiczny, zwracając uwagę na ambiwalencję objawów, z kolei w świecie chrześcijańskim pojęcie to rozumiane było jako choroba duszy, acedia (już w pismach ojców Kościoła, w pierwszych wiekach chrześcijaństwa, zauważa się opisy pewnych stanów zgnuśnienia, nade wszystko u mnichów), pojmowana negatywnie, jako grzech. Czasy nowożytne przyniosły kolejne interpretacje: wiedzę czerpano z pism antycznych, odwołując się m.in. do medycyny humoralnej. Renesansowi humaniści états d'âme przedstawiali w sztuce na wiele sposobów, m.in. jako „narodową” przypadłość: spleen, Weltschmerz, ennui, szaleństwo. Koncepcje Arystotelesa i Platona uzupełniono o nowe interpretacje, powstały liczne traktaty. Melancholię rozumie się różnorodnie: jako stan ducha medytującego chrześcijanina, łączy się ją z pojęciem mal du siècle; to również stan rozedrgania wewnętrznego objawiającego się poprzez twórcze uniesienie, refleksja wypływająca z przemyśleń egzystencjalnych (cf. Starobinski 2017; Fischer 2013; Wroniszewski 2015; Bałus 1996; Bieńczyk 2014; Skwara i Skwara 1997; Sadkowska b.d.; Raubo 2012). 
Melancholia jako obiekt zainteresowania teoretyków i badaczy od starożytności była obecna w dyskursie medycznym, stopniowo jednak pojawiała się także na gruncie antropologicznym - w filozofii, psychologii, socjologii, teologii czy świecie sztuki, uzyskując również powodzenie i rozgłos jako „poetycka melancholia” (Dybizbański i Mazur 2016, 10). W polskim dyskursie literaturoznawczym zainteresowanie badaczy tropami melancholicznymi - swoistą „modę melancholiczną"3 - zauważa się od lat dziewięćdziesiątych XX wieku4, choć niemalże z roku na rok pojawiają się nowe opracowania ${ }^{5}$. Na melancholiczny wymiar twórczości Tokarczuk zwracali uwagę m.in. Marta Gąsowska (Gąsowska 2012), Katarzyna Majdzik (Majdzik 2012) czy Adam Lipszyc (Lipszyc 2014), wydaje się jednak, że twórczość autorki Ksiag Jakubowych warta jest osobnej rozprawy.

„Celem pielgrzymowania jest zawsze inny pielgrzym” (Tokarczuk 2007, 138) - to zdanie z Biegunów Olgi Tokarczuk, której jednym z bohaterów jest Filip Verheyen, XVII-wieczny anatom z Flandrii, pojawia się w książce kilkakrotnie. Tokarczuk podkreśliła, że fakt spotkania z człowiekiem jest dla niej ważny, a pisanie stanowi podróż, która prowadzi do poznania Innego (Szostak 2018). Tym właśnie doświadczeniem dzieli się w powieściach. Postaci pojawiające się w Biegunach nie są przypadkowe, jak zauważył Dariusz Nowacki - łączy je jedno: to ekscentrycy (Nowacki 2007). Przemieszczanie się z miejsca na miejsce jest ich swoistą strategią życiową. Włóczenie się bez celu, błądzenie, podróżowanie bez wytchnienia to motywy melancholiczne, które Marek Bieńczyk uznał za jedne z najczęściej pojawiających się symptomów ogarniających melancholików (Bieńczyk 2014, 66)7 Węższe ujęcie terminu „podróżowanie” odsyła do psychologii - wskazuje Agnieszka

3 Określenie Aliny Świeściak (Świeściak 2010, 5).

4 W sposób szczególny zainteresowanie tą kategorią ujawniają badacze współczesnej poezji polskiej (cf. m.in. Kisiel 2010; Felberg 2009; Świeściak 2010; Małczyńska 2014).

5 Imponującym dziełem zawierającym antologię rodzimych tekstów z dziedziny psychopatologii jest książka Miry Marcinów Historia polskiego szaleństwa. Choć autorka we wstępie do opracowania przyznała, że jest ono „próbą stworzenia archeologii polskiego szaleństwa”, tom ten zainteresuje nie tylko psychologów i psychiatrów, ale także literaturoznawców dzięki zamieszczonym w Epilogu tekstom źródłowym i ikonografii (cf. Marcinów 2018).

6 O. Tokarczuk, Bieguni, s. 138, od tej pory z oznaczeniem B, z odniesieniami do stron w nawiasach w tekście.

7 Wątek tułacza, włóczęgi, turysty jest od wieków silnie obecny w literaturze, szczególnie doby romantyzmu (topos homo viator). Janina Kamionka-Straszakowa wskazała, że motyw ten „aktualizuje określoną koncepcję antropologiczną i aksjologiczną” (cf. KamionkaStraszakowa 1992, 10). 
Nęcka - obrazując (auto)terapeutyczną i (auto)poznawczą wędrówkę w głąb swojego „ja” (Nęcka 2011). Powieść wyróżniona Nagrodą Bookera obrazuje więc konieczność zmiany i ruchu:

[Książka - K.W.] ma więc strukturę muzycznej fugi, w której poszczególne motywy powracają przekształcone i wzbogacone. Dodajmy, że „fuga” znaczy też „ucieczka”, w psychologii zaś nazwą tą określa się nerwicowe zaburzenie bliskie popędowi do włóczęgi i bezustannej podróży.

(Franaszek 2007)

Motyw podróży kształtuje opowieści od pierwszej do ostatniej: postaci pozostają w ruchu, wyruszają w nieznane, niekiedy, przymuszone, zatrzymują się ${ }^{8}$. Pisarka przyznała, że temat ten stanowi dla niej główną oś książki - chodziło o wyeksponowanie postaci kloszarda oraz każdego, „kto wypadł poza stabilny porządek" (Pawłowski 2008). Bieguni są zatem metaforą współczesnych podróżnych, dla których permanentne poruszanie się oznacza ucieczkę przed złem próbującym odebrać człowiekowi wolność (Tokarczuk 2008). Nie jest to jednak jedyna wykładnia tych historii. Podróż polega nade wszystko na indywidualnym doświadczeniu jednostki, jest „sprawą osobistą” - konstatuje Dariusz Nowacki (Nowacki 2007). Tokarczuk opisuje człowieka także poprzez aspekt natury ludzkiej i podróży w głąb ciała, które nie jest „głuche” na psychiczne cierpienie - organizm zapamiętuje bowiem

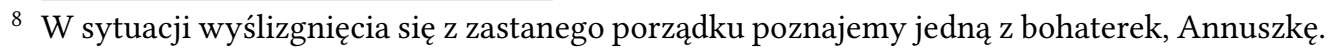
Kobieta pochodzi z miasta, w którym wszyscy „cierpieli na jakąś dziwną chorobę, to był wielki, ukryty głęboko w ciele, pod ubraniami, smutek” (B 273). Jej życie zapowiadało się pomyślnie, lecz potoczyło się inaczej - kobieta obwinia siebie za nieuleczalną chorobę syna. Pustkę wewnętrzną zapełnia wyobrażeniami o lepszym, innym życiu. Jej spacer raz w tygodniu po XX-wiecznej Moskwie można określić słowami Bieńczyka jako przejaw „wygnania i samotności w coraz bardziej anonimowym mieście”. Letarg melancholiczny, w którym się znajduje, „melancholia dogasających marzeń” (określenie Adama Lipszyca) objawiająca się niedopasowaniem, poczuciem obcości, powodowane są przekonaniem, że w młodości utraciła coś bardzo cennego, czego nie może odzyskać - wolność. Julia Kristeva wskazuje, że jest to postawa „triumfalistycznej abnegacji” - bohaterka skupiona jest wyłącznie na kontrolowaniu dziecka. Syn, Pietia, w pojęciu Kristevej, stał się „elementem” odbierającym mowę w i tak małomównym świecie matki. Przypomnijmy, że następstwo odruchów, uznawanych za normalne ze względu na częstotliwość występowania, w melancholii ulega zahamowaniu, w konsekwencji czego człowiek cierpiący nie jest w stanie niczego ze sobą powiązać, nie reaguje, nie mówi. Annuszka podejmuje próbę wyrwania się z letargu poprzez ucieczkę $\mathrm{z}$ domu, lecz powraca do niego, tym samym prawdopodobnie wzmacniając w sobie melancholijne „dziedzictwo” (cf. Starobinski 2017; Bieńczyk 2014; Lipszyc 2014; Kristeva 2007). 
i komunikuje swoje problemy poprzez ciało i jego chorobę (Cieśla 2018), nieraz ujawniającą się w dolegliwościach psychosomatycznych, których manifestacja dokonuje się w widoczny sposób u Filipa Verheyena ${ }^{9}$.

\section{Wnikanie w siebie}

Filip Verheyen, XVII-wieczny anatom z Flandrii zafascynowany ludzkim ciałem, jako niespełna trzydziestolatek traci lewą nogę w wyniku nieszczęśliwego wypadku. Ambitny młody student teologii w Lejdzie z dnia na dzień jest zmuszony podporządkować się swojemu kalectwu i zmienić dotychczasowe życie. Toczy walkę o zdrowie i powraca do częściowej sprawności, doświadczenie choroby jednak go zmienia. Na całe życie pozostanie bowiem kaleką, dla którego poruszanie się będzie równoznaczne z mozołem, trudem. Kaleką osobliwym, należy dodać, któremu zawsze towarzyszy obcięta kończyna, po amputacji zakonserwowana odpowiednią substancją i zanurzona w alkoholu. Bohater nie potrafi rozstać się ze swoją nogą, nie może pogodzić się ze stratą, więc trzyma kończynę przy sobie, blisko, u wezgłowia łóżka lub na stole (B 205-239).

Wydaje się, że poczucie tożsamości osobowej Verheyena jest doświadczeniem ściśle związanym z nieuzmysłowioną pamięcią ciała. William James uznaje to odczucie za fundamentalny czynnik tożsamości, ale także jednolitej świadomości człowieka. Musi on nosić w sobie podskórne poczucie, że „to samo, dawne ciało trwa” (James 2002, 235). Flandryjski naukowiec tego doświadczenie nie zna, wraz z amputacją nogi traci poczucie tożsamości, a strata wypełnia jego egzystencję i staje się przyczyną choroby. Richard Shusterman przekonuje, że pamięć tożsamości w ciele łączy się z pamięcią przestrzenną:

Ta nieuzmysłowiona pamięć umiejscowienia w przestrzeni jest oczywiście głęboko zakotwiczona w somie, która zasadniczo określa lokalizację człowieka oraz poczucie miejsca: perspektywę na świat i współrzędne ukierunkowywania się w nim. (Shusterman 2012, 124)

9 Postacią zmagającą się z nieuzmysłowioną pamięcią ciała jest także Marek Marek z Domu dziennego, domu nocnego. Wszystko, co robi, prowadzi go do stanu nieświadomości (poprzez upojenie alkoholowe), pożąda bowiem przerwania pamięci ciała, które w stanach trzeźwości manifestuje lęk. Bohater mówi swoim ciałem, nie będąc tego świadomym - za Jacques'em Lacanem powiemy, że mówi więcej, niż zdaje sobie sprawę (cf. Shusterman 2012; Markowski 2007). 
W sposób metaforyczny utratę kończyny można więc uznać za wchodzenie Filipa w zagubienie wobec świata, który go otacza. Naukowiec po kilkumiesięcznej rekonwalescencji rezygnuje z młodzieńczych marzeń i decyduje się na studia anatomiczne. Szybko osiąga w tej dyscyplinie sukcesy, obejmując stanowisko rektora uniwersytetu w Leuven. Po niedługim czasie wycofuje się jednak z życia akademickiego i osiada w domku na wsi. Jego perspektywa na świat znacząco się wówczas zmienia: zajmuje małą przestrzeń, nie wychodzi z domu, a ulubioną pozycją staje się siedzenie z przygarbionymi plecami nad stołem z rysunkami. Choć nie urodził się pod znakiem Saturna, obrazem kalekiego naukowca wpisuje się w kształtujący się od XV do XVIII wieku typ dzieci planet ${ }^{10}$. Ponadto pisze listy do amputowanej nogi - czynność ta, wskazuje Piotr Śniedziewski, może wynikać ze złego samopoczucia, smutku, doświadczenia nicości (Śniedziewski 2011, 79).

Od momentu wypadku życie Filipa ustawicznie uprzykrza pewna dolegliwość - cierpi na bóle, które nazywa fantomowymi; odczuwa boleść amputowanej nogi:

- Boli mnie.

Tamten rozumie, że chodzi mu o wyciągnięty na stołku kikut, ale Filip Verheyen wskazuje dalej, na nie istniejącą już część ciała, w przestrzeń.

- Bolą cię blizny? [...]

- Boli mnie noga. Czuję ból wzdłuż kości i do szaleństwa doprowadzają mnie stopy. Paluch i jego staw. Są opuchnięte, gorące, skóra swędzi. O tu pochyla się i wskazuje małe zagniecenie na pościeli. Willem milczy. Co ma powiedzieć? ( B 211).

Filip staje się innym człowiekiem - „często zapada na osłabienie i melancholię” (B 231). Nie mówi nikomu o swoich dolegliwościach, ponieważ nie chce, aby oskarżono go o niepoczytalność. Sąd ten nie wydaje się przesadzony. W XVII wieku chorobę „szału i zachwycenia”, „przygnębienia i lęków” przypisywano ludziom wybitnym w dziedzinach filozofii sztuki i polityki (Skwara i Skwara 1997, 36), które jako jedyne potrzebowały „boskiego szaleństwa" ${ }^{11}$. Nauka, anatomia, medycyna - oparte na umyśle, wiedzy, rozsąd$\mathrm{ku}$, badaniach - tego typu twórczą pasję uważały za ludzką niepoczytalność.

${ }^{10}$ Ryciny przedstawiały saturnijczyków jako chłopów, drwali, żebraków, kaleki, więźniów, skazanych przestępców, myślicieli. Ponadto Saturna uznawano wówczas za dawcę mądrości i „górnego, wysokiego natchnienia” (cf. Klibansky, Panofsky i Saxl 2009, 423-426).

${ }^{11}$ Neoplatonicy florenccy łączyli pojęcia „szału melancholicznego” z Platońskim „boskim szaleństwem". 
Flandryjski naukowiec nie umie sobie pomóc, obiera więc inny kierunek zatapia się w obserwacjach ludzkiego ciała, odseparowując się od ludzi.

Wydaje się, że utrata nogi miała także bezpośrednie przełożenie na pamięć przestrzenną bohatera, który nie wraca do miejsc z przeszłości (zapomina o nich?), więcej - stopniowo izoluje się od życia naukowo-uniwersyteckiego, które rozpoczął po wypadku. W sposób szczególny ciekawi go amputowana noga: bacznie przypatruje się martwym tkankom, które kiedyś były częścią jego ciała. Poświęca długie godziny na badania, ślęczy przy mikroskopie, robi notatki, szkicuje. Znaczące, że anatom bez nogi staje się ekspertem od budowy organizmu ludzkiego. Zamiast ludzi otaczają go tkanki mięśni, wiązki nerwów i przebiegi naczyń krwionośnych. Ciało ludzkie, jako enigmatyczne „locus bezosobowego istnienia”, jest też miejscem, gdzie - jak spostrzega Shusterman - życie ukrywa się przed światem, gdzie człowiek wycofuje się od zaangażowania w obserwację i działanie (Shusterman 2012, 73). Dzięki ucieczce ze świata w stronę ciała Filip może pogrążyć się w myślach o swojej stracie, cały czas jednak prowadząc „szczegółowe prace na temat mięśni i ścięgien” (B 231). Ciało zamyka go na świat, lecz jednocześnie jest czymś, co „otwiera na nowe, inne i niezbadane”, wprowadza w nową sytuację (Merleau-Ponty 2001, 119-120). Naukowiec wybiera pracę nad atlasem ludzkiego ciała, a jego życie skupia się na szczególe: rysunki są „starannie oznaczone, absolutnie przejrzyste, doskonałe” (B 208). Verheyen nosi w sobie melancholijne rysy, które ujawniają się w postawie wnikliwego obserwatora: „nikt nie mógł mu dorównać ścisłością umysłu i rzetelnością obserwacji” (B 229). Kamila Dzika-Jurek zauważyła, że współcześnie mówi się o wzroku melancholików wyłącznie jako synonimie apatii i zniechęcenia i zapomina się o tym, iż niegdyś wskazywano na nich jako na ludzi „wnikliwej obserwacji”. Jeszcze na początku wieku XX metafora „oka Dürera” oznaczała „niesłychaną intensywność percepcji” (Dzika-Jurek 2014, 26) ${ }^{12}$. Wydaje się, że w badaniach melanchologicznych należy rozróżniać modalności wzroku melancholika - ten o niesłychanej intensywności percepcji Bieńczyk w książce Oczy Dürera. O melancholii romantycznej wiąże z „mocną” melancholią „słabego” podmiotu, która prowadzi do kryzysu egzystencjalnego, ideowego i „wyzwala doświadczenie rozpoznania bytu” (Bieńczyk 2002). Z kolei spojrzenie apatyczne, wzrok jedynie prześlizgujący się po

\footnotetext{
${ }^{12}$ Autorka cytuje fragment rozprawy Rufusa z Efezu charakteryzujący melancholików: „Ci, którzy są przenikliwi i wyjątkowo pojętni, łatwo popadają w melancholijne nastroje, ze względu na swą wrażliwość, dar przekonywania i żywą wyobraźnię".
} 
przedmiotach, wskazuje Dzika-Jurek, należałoby sytuować raczej po stronie depresji (Dzika-Jurek 2014, 25). Ten drugi stan wiąże się z kategoriami maski melancholika i „niezrozumieniem jako naczelnym rekwizytem”, które według Alicji Kuczyńskiej stanowi magiczny „kokon bezpieczeństwa” (Kuczyńska 1999, 17).

Atlas „Corporis Humani Anatomia” przyniósł naukowcowi sławę w świecie nauki, jednak nie dostarczył odpowiedzi na nękające go pytania. W swoich notatkach zapisał: „Dlaczego mnie boli to, co nie istnieje? Dlaczego odczuwam brak, czuję nieobecność?” (B 238). Flandryjczyk wierzył, że wiedza może przynieść mu ukojenie: „to ona uwolni nas od smutku, od rozpaczy, od zawiści i trwogi, które są naszym piekłem” (B 237). Początkowo jego naukowe podróże „do własnego ciała, do własnej odciętej kończyny” (B 239) przynosiły mu ulgę i przyczyniały się do postępu naukowego. Im jednak dłużej ta swoista podróż trwała, tym mocniej Verheyen izolował się od świata zewnętrznego. Gdy jego jedyny przyjaciel nieoczekiwanie przyszedł w odwiedziny, naukowiec przyjął go z rezerwą. Poznajemy, że separacja jest zamierzona:

Będzie [...] udawał, że nie mógł znaleźć gospodyni, tymczasem wcale jej nie szukał. Będzie udawał, że kojarzy wszystkie nazwiska, które padają z ust przybysza, choć w rzeczywistości nie jest dobrze z jego pamięcią. Jest rektorem uniwersytetu w Leuven, ale od lata zaszył się na wsi i skarży się na zdrowie (B 206-207).

Melancholia bohatera, początkowo będąca stanem wrażliwości ujawniającej się poprzez intensywne przeżywanie własnej egzystencji, przeobraża się w stan pustki i manifestowanego zniechęcenia, które Kuczyńska określa jako „chorobę i destrukcję” (Kuczyńska 1999, 9). Badacz z czasem coraz bardziej izoluje się od ludzi, towarzystwo najbliższego mu współpracownika, przyjaciela, nie jawi się jako interesujące - jest wręcz niepożądane: „Filip musi się pilnować, żeby na jego twarzy nie pojawił się wyraz zniecierpliwienia i grymas właściwy komuś, kto znalazł się nagle w samym środku przeraźliwego hałasu” (B 206).

Zauważmy, że w dzieciństwie Filip był „spokojnym, cichym chłopcem” (B 214), nie stronił od nauki, a słowa vanitas vanitatum, które słyszał od pastora w trakcie nabożeństw, traktował jako powitanie. Dzieciństwo ukształtowało go w taki sposób, że jako dorosły widział tylko „rzeczy małe”:

Jego ciało od początku najlepiej czuło się w tej szczególnej pozycji - pochylone nad stołem, z nogami wspartymi o drewniane drążki, z kręgosłupem 
wygiętym w łuk i dłońmi zaopatrzonymi w piórko, którego wcale nie interesują dalekosiężne cele, ale mierzy blisko, w królestwo detalu, w kosmos szczegółów, kresek, punktów, gdzie rodzi się obraz (B 214).

Jego spokojne usposobienie przyczyniło się do młodzieńczego zamiłowania do rysowania, rycia, drukowania, które wymagały czasu i uwagi. Cierpliwość ćwiczył podczas długich godzin spędzonych z rysikiem przy stole, przyzwyczajając się do milczenia i samotności. A jednak jako student nie był wyalienowany, co więcej - jego małomówność i pełne skupienie na pracy przyniosły mu sukces $\mathrm{w}$ świecie naukowym. Z czasem jednak $\mathrm{w}$ życiu badacza na plan pierwszy wysuwa się temat nieprzepracowanej straty. Ciało staje się przekaźnikiem głęboko skrywanych emocji, niedoskonałym sposobem komunikowania się ze światem: badacz stopniowo osuwa się w bezruch, otępienie. Pojawia się przepaść między potencjalnymi możliwościami intelektualnymi a chęcią ich konkretyzacji, świadcząca o towarzyszącym postawie melancholii samoujawnianiu (Kuczyńska 1999, 18).

Wydaje się, że samotna praca nad atlasem ludzkiego ciała jest próbą oswojenia straty poprzez uświadomienie jej sobie, narysowanie - swoista autoterapia z rysikiem w dłoni. Bieńczyk tłumaczy, że w leczeniu melancholii chodzi przede wszystkim o rozproszenie smutnych myśli różnymi zajęciami (Bieńczyk 2014, 143). W przypadku Verheyena czynność ta nie sprawdza się, ponieważ praca w pustelniczym otoczeniu powoduje daleko idącą separację, przedmiot działań natomiast - atlas - nie pozwala na oddalenie przykrych myśli. Naukowiec cały czas zderza się z przedmiotem straty, obcuje z nim zarówno materialnie (zaimpregnowana kończyna), jak i niematerialnie (rysowanie kończyny). Willem van Horssen po jednym ze spotkań konkluduje:

Gdy zdałem sobie sprawę, że jestem jedyną osobą, z którą się kontaktował, zrozumiałem też, iż Filip przekroczył niewidzialną granicę, zza której nie ma już powrotu (B 221).

Zauważmy, że amputacja, której Verheyen musiał się poddać ze względów zdrowotnych - powoli, lecz konsekwentnie, z roku na rok, prowadzi go do śmierci - bóle fantomowe stają się bowiem nie do zniesienia. Bohater pod koniec życia pogrąża się w apatii, którą tłumaczono dokuczliwymi napadami melancholii: „Teraz czarna żółć osiągnęła poziom jego mózgu, może z powodu tych bólów” (B 233). Naukowiec przekroczył granicę, za którą czaiło się groźne niebezpieczeństwo - potrzebna do pracy samotność geniusza, „mocna” melancholia „słabego” podmiotu przestała objawiać się epifanicznie, stając się brzemieniem zbyt ciężkim, aby móc żyć z nią w przyjaźni. 
Van Horssen nie mógł się nadziwić, jak wielka zmiana zaszła w jego mistrzu. Miewał wrażenie, że podczas rozmowy „gospodarz jest pochłonięty czymś innym” (B 207). Ostatecznie doszedł do przekonania, że: „być może samotność rozciągnęła myśli [Filipa - K.W.] w długie smugi i przyzwyczaiła go do wewnętrznych dialogów" (B 207).

Warto zwrócić uwagę na fakt rozszczepienia ontologicznego, jakiego zaznaje bohater. Dualizm substancji duszy i ciała jest zagadnieniem filozoficznym rozważanym od starożytności. W teorii dualistycznej ciało i umysł są dwiema odrębnymi substancjami, a zjawiska psychiczne zachodzą w odmiennej od ciała substancji duchowej (Ajdukiewicz 2004, 95-97). Po amputacji nogi Filip odczuwał bóle, które nie mają nic wspólnego z brakującą kończyną, naukowiec nie umiał ich zlokalizować. Zjawiska znane nam z doświadczenia wewnętrznego, takie jak myślenie, cierpienie, odczuwanie emocji itp., wymagają innego podłoża niż ciało: „Tym podłożem są dusze - one myślą, czują, cieszą się, cierpią" - zauważył Kazimierz Ajdukiewicz (Ajdukiewicz 2004, 95-97). A zatem cierpienie, którego doświadcza bohater, wiąże się z psychiką - to brak akceptacji straty jest czynnikiem wywołującym ból. Śniedziewski zwrócił uwagę, że oswojenia straty można dokonać na dwa sposoby: epikurejski, poprzez zastąpienie ubytku nową przyjemnością, lub poprzez spoglądanie za tym, co się utraciło (Śniedziewski 2011, 152). Nie dokonuje się to jednak u Verheyena - od momentu amputacji obiekt straty cały czas towarzyszy bohaterowi, którego pamięć mięśniowa manifestuje się jednak poprzez pamięć traumatyczną (Shusterman 2012, 131).

Jako młody naukowiec Verheyen podczas pracy siadał przy stole, w plamie światła, które wpadało przez okno, i badał rozciągnięte na stole tkanki. Analityczne spojrzenie, brak zawahania, pewne i szybkie ruchy rysika tworzyły bardzo dokładny obraz, wskazując na akcentowaną już intensywność i siłę melancholijnego spojrzenia. W chorobie perspektywa ta się zmienia. Sytuację naukowca dobrze opisują słowa Jana Białostockiego, piszącego o Melancolii I Dürera: „smutny i piękny geniusz bezczynnie siedzi wśród nagromadzonych [...] przyrządów” (Białostocki 1970, 37). Spojrzenie bohatera stało się ekwiwalentem jego emocji i świadczy o niemożności działania:

Siedział przy południowym oknie i patrzył przez nie, ale nie miałem wątpliwości, że jedyne, co może oglądać ten człowiek, to swoje wewnętrzne obrazy. Nie zareagował na moje wejście, spojrzał tylko na mnie bez ciekawości i bez żadnego gestu, a potem odwrócił twarz do okna (B 232).

Zagubienie bohatera w rzeczywistości bierze się z głębokiego zanurzenia się $\mathrm{w}$ siebie. Przeciętny człowiek nie jest w stanie powstrzymać procesu 
myślowego, a u melancholika, jakim był Verheyen, proces ten, pogłębiony ponadto od momentu straty nogi, jest wyjątkowo uporczywy. Günter Grass zauważył, należałoby dodać - w przeciwieństwie do metafory „oka Dürera” - że współcześnie melancholicy wyglądają, patrzą, albo czują się: żałośnie, osowiale, minorowo (Grass 1999, 230-231). Stan ten doskonale pasuje też do flandryjskiego naukowca. Proces odchodzenia, wchodzenie w martwotę i bezwładność ciała łączy się u niego z wpatrywaniem się w okno (przez okno?), spojrzeniem już bez wyrazu, z postawą osowiałą, nawet zgnębioną. Pozycja ta nawiązuje do alegorii melancholii, którą według Bieńczyka niemal zawsze przedstawia się jako figura sedens, czyli „postać siedzącą w smutnym zamyśleniu”, z motywem „twarzy opadającej” (Bieńczyk 2014, 29).

Wydaje się, że XVII-wieczna postać pochylonego anatoma z rysikiem w dłoni ma coś wspólnego z zamyślonym geniuszem z miedziorytu Dürera. Choć renesansowy artysta w podejmowanej „refleksji” nad tym zjawiskiem zatrzymał się na rycinie, jego wkład w teorie melancholiczne jest nie do przecenienia $^{13}$. Bonnie Noble, doktor historii sztuki, w eseju dotyczącym ryciny wskazuje, że bezwładność postaci, którą widzimy, powoduje chaos i zaniedbanie ogarniające jej rzeczywistość (Noble b.d.). Podobnie wygląda otoczenie anatoma z Flandrii. Gdy Willem van Horssen przychodzi przebadać swojego mistrza, dostrzega leżącą na stole nogę, rozebraną na tysiące nieskończenie małych części. Zwoje ścięgien i mięśni zajmują całą powierzchnię stołu, na którym wcześniej zawsze panowała czystość. Co więcej, służący Filipa od pewnego momentu lękał się wchodzić do pokoju naukowca, był przerażony jego stanem, dlatego postanowił wezwać lekarza. Zdaje się, że stan, w którym znajduje się postać z miedziorytu Dürera, można także przypisać badaczowi z Flandrii. Jak zauważyła Noble, postać ta wykazuje postawę bezsilności, jej będące w nieładzie otoczenie koresponduje z postawą zgarbienia, zamyślenia. Podobnie dzieje się w przypadku Filipa - „apatia”, „zły stan”, zatrzymanie się $\mathrm{w}$ miejscu, brak interakcji $\mathrm{z}$ otoczeniem stały się przyczyną wezwania lekarza.

Powodem cierpienia anatoma była strata. Bóle fantomowe nie stanowiły bezpośredniej przyczyny udręk, ale wskazywały na obiekt utracony. Ostatecznie łączyły się też z pogłębiającą się zadumą, z bólem duszy pochodzącym od amputowanej nogi. Willem van Horssen pod koniec życia rozpoznał u swojego nauczyciela poważną melancholię. Jak zauważył Śniedziewski,

${ }^{13}$ Wskazuje na to m.in. M. Bieńczyk, pisząc, że jest to dzieło „w długiej historii melancholii najważniejsze" (cf. Bieńczyk 2014, 5). 
poszukiwanie przyczyn cierpienia przez melancholika generuje potrzebę „ciągłego wyobrażania sobie innych okoliczności i miejsc, gdzie dałoby się żyć” (Śniedziewski 2011, 183). Ostatnie miesiące życia anatom spędził w samotności, w otępieniu, na które nie dało się zaradzić, i oddawał się rozmyślaniom nie mogły one jednak przynieść pociechy, ponieważ „spojrzenie ku własnemu wnętrzu nie zapewnia poznawczego komfortu”, komentuje Śniedziewski (Śniedziewski 2011, 131).

To odseparowanie się od świata, rezygnacja z wszelkich aktywności i kontaktu z ludźmi przyspieszyły postęp choroby. Naukowiec w tamtym czasie nie daje sobie prawa do życia, i to staje się powodem jego zguby. Bieńczyk zauważa, że „strata melancholijna polega na tym, iż coś zostało utracone i dlatego ciągle jest” (Bieńczyk 2001, 62-63). Strata - w przypadku Flandryjczyka nie została przyswojona, opanowana. Kuczyńska wskazała, że melancholik, pozornie pochłonięty cierpieniem, potrzebuje „widowni, publiczności dyskretnej, odległej, nie ingerującej, ale obecnej w jego własnym osobliwym teatrze życia" (Kuczyńska 1999, 18). Jeżeli ta swoista relacja z drugim człowiekiem nie zaistnieje, a w jej miejsce pojawia się poczucie samotności, nadchodzi proces zanurzania się w śmierć zarówno psychiczną, jak i fizyczną.

\section{Podsumowanie}

Melancholia w twórczości Tokarczuk jawi się jako problem dotykający natury ludzkiej. Charakteryzuje człowieka przygnębionego, rozmyślającego, rozpamiętującego - nie jest stanem permanentnym, objawia się w przeróżny sposób. Czasem jej towarzystwo jest ciche i prawie bezbolesne, innym razem przeżywane jako ogromne cierpienie psychiczne. Galeria postaci, którą prezentuje w swej twórczości pisarka, zdaje się to potwierdzać i warta jest osobnych analiz - to między innymi: Krystyna Popłoch i Marta (Dom dzienny, dom nocny), Florentynka i dzieci Saturna - Izydor i Ruta (Prawiek i inne czasy), bezimienna bohaterka Szafy, Erna Elzner (E.E.), czy choćby swoiste trio babka-córka-wnuczka z Ostatnich historii.

Co więcej, Tokarczuk nie tylko tworzy bohatera melancholicznego, ale także narrację powieści prowadzi często w sposób poszarpany, w postaci krótkich historii, które mogłyby się ciągnąć w nieskończoność. Jedyną przeszkodą jest dla pisarki rama opowieści, która $\mathrm{z}$ reguły musi mieć 
zakończenie $^{14}$. Ta niezwykła właściwość écriture melancolique charakteryzuje się mnogością cytatów i dygresji, które według Bieńczyka pisarze stosują w nadziei zapełnienia uczucia pustki (Bieńczyk 2014, 35) - to ono konstytuuje bowiem owo melancholijne doświadczenie.

\section{Bibliografia}

Ajdukiewicz, Kazimierz. 2004. Zagadnienia i kierunki filozofii. Teoria poznania. Metafizyka. Warszawa: Wydawnictwo Antyk.

Bałus, Wojciech. 1996. „Świat a melancholia”. [w:] Mundus melancholicus. Melancholiczny świat $w$ zwierciadle sztuki, 11-20. Kraków: Universitas.

Białostocki, Jan. 1970. Albrecht Dürer. Warszawa: Wydawnictwo Ruch.

Bieńczyk, Marek. 2001. „Marek Bieńczyk o winie i melancholii”. Opracowane przez Katarzyna Janowska i Piotr Mucharski. [w:] Rozmowy na nowy wiek. T. 2. Kraków: Znak.

2002. Oczy Dürera. O melancholii romantycznej. Warszawa: Wydawnictwo Sic!.

2014. Melancholia. O tych, co nigdy nie odnajda straty. Warszawa: Świat Książki.

Cieśla, Aneta. 2018. „Ciało choruje razem z duszą. Zaburzenia psychosomatyczne”. Deon.pl. Dostęp: 05.03.2020. https://deon.pl/inteligentnezycie/psychologia-na-co-dzien/cialo-choruje-razem-z-dusza-zaburze nia-psychosomatyczne, 461462 .

Dybizbański, Marek i Aneta Mazur (oprac.). 2016. Światy melancholii: w 50olecie „Melancholii” Albrechta Dürera. Opole: Wydawnictwo Uniwersytetu Opolskiego.

Dzika-Jurek, Kamila. 2014. „Problem ciężaru. Melancholia w twórczości Magdaleny Tulli”. Praca doktorska, Uniwersytet Śląski w Katowicach. Dostęp: 25.03.2010. http://www.sbc.org.pl/Content/139135/doktorat 3519.pdf.

\footnotetext{
${ }^{14}$ Przychodzi mi na myśl Podróż sentymentalna przez Francję i Włochy Laurence’a Sterne’a, która sprawia wrażenie urwanej poprzez ostatnie zdanie powieści: „Tak, że kiedy wyciągnąłem rękę, schwyciłem pokojówkę za...”. Tak jak Sterne w zaskakujący sposób kończy powieść, jak Burton, mnożąc autorów swej przepastnej księgi, przekonuje o doświadczeniu bezkresu melancholii, tak Tokarczuk stosuje zabiegi narracyjne, a nade wszystko pisze, snuje opowieść, tka słowa - jak Szeherezada pozostająca przy życiu dzięki swej opowieści.
} 
Felberg, Karolina. 2009. „Melancholia i ekstaza”. Projekt totalny w twórczości Andrzeja Sosnowskiego. Warszawa: Instytut Badań Literackich PAN.

Fischer, Jakub. 2013. „Melancholia, choroba, szaleństwo - kompleks staropolskiego poety metafizycznego: idee, inspiracje, motywy, postawy". Symbolae Philologorum Posnaniensium Graecae et Latinae XXIII/2: 171-190.

Franaszek, Andrzej. 2007. „Wezwanie niepokoju”. Gazeta Wyborcza, 16.10.2007.

Gąsowska, Marta. 2012. „Między nostalgią a melancholią - o miejskiej przestrzeni w »Powidokach« Marka Nowakowskiego”. Bez Porównania. Czasopismo naukowe studentów komparatystyki Uf 1: 85-98.

Grass, Günter. 1999. „O bezruchu w postępie”. Tłum. Sławomir Błaut. [w:] G. Grass, Z dziennika ślimaka. Gdańsk: Wydawnictwo Morskie.

James, William. 2002. Psychologia. Kurs skrócony. Tłum. Michał Zagrodzki. Warszawa: Wydawnictwo Naukowe PWN.

Kamionka-Straszakowa, Janina. 1992. Zbtąkany wędrowiec. $Z$ dziejów romantycznej topiki. Wrocław: Ossolineum.

Kisiel, Joanna. 2001. Retoryka i melancholia. O poezji fana Lechonia. Katowice: Wydawnictwo Uniwersytetu Śląskiego.

Klibansky, Raymond, Erwin Panofsky i Fritz Saxl. 2009. Saturn i Melancholia. Studia z historii, filozofii, przyrody, medycyny, religii oraz sztuki. Tłum. Anna Kryczyńska, 25-74. Kraków: Universitas.

Kristeva, Julia. 2007. Czarne stońce. Depresja i melancholia. Tłum. Michał Paweł Markowski i Remigiusz Ryziński. Kraków: Universitas.

Kuczyńska, Alicja. 1999. „Melancholijne „ja”. Pomiędzy źródłem inspiracji a przypadłością kliniczną". [w:] Alicja Kuczyńska, Piękny stan melancholii. Filozofia niedosytu i sztuka. Warszawa: Wydział Filozofii i Socjologii Uniwersytetu Warszawskiego.

Lipszyc, Adam. 2014. „Melancholia zbawienia”. Dwutygodnik. Dostęp: 13.03.2020. https://www.dwutygodnik.com/artykul/5574-melancholia -zbawienia.html.

Majdzik, Katarzyna. 2012. „Oblicza melancholii. »Szafa« Olgi Tokarczuk i jej chorwacki przekład”. Przekłady Literatur Stowiańskich 3/1: 252-266.

Małczyńska, Anna. 2014. Z padtych wstawanie: o melancholii w pisarstwie Edwarda Stachury. Kraków: Nomos.

Marcinów, Mira. 2018. Historia polskiego szaleństwa. Tom 1. Stońce wśród czarnego nieba. Studium melancholii. Gdańsk: słowo/obraz terytoria. 
Markowski, Michał Paweł. 2007. „Przygoda ciała i znaków. Wprowadzenie do pism Julii Kristevej”. [w:] Julia Kristeva, Czarne stońce. Depresja i melancholia. Tłum. Michał Paweł Markowski i Remigiusz Ryziński. Kraków: Universitas.

Merleau-Ponty, Maurice. 2001. Fenomenologia percepcji. Tłum. Małgorzata Kowalska i Jacek Migasiński. Warszawa: Fundacja Aletheia.

Nęcka, Agnieszka. 2011. „W pułapce metazdjęć Olgi Tokarczuk i Andrzeja Stasiuka”. artPAPIER 15/16 (183-184). Dostęp: 13.03.2020. http:// artpapier.com $/$ index.php?page $=$ artykul $\&$ wydanie $=135 \&$ artykul $=2924$.

Noble, Bonnie. b.d. „Dürer - Melencolia”. Khan Academy. Dostęp: 15.09.2019. https://pl.khanacademy.org/humanities/renaissancereformation/north ern/durer/a/durer-melancholia.

Nowacki, Dariusz. 2007. „Podróżowanie jest koniecznością”. Tygodnik Powszechny. Dostęp: 13.03.2020. https://www.tygodnikpowszechny.pl/ podrozowanie-jest-koniecznoscia-138350.

Pawłowski, Roman. 2008. „Nike 2008 dla Olgi Tokarczuk - Bieguni książką roku”. Gazeta Wyborcza. Dostęp: 13.03.2020. https://wyborcza.pl/ 1,75248,5770552,Nike_2008_dla_Olgi_Tokarczuk__Bieguni_ksiaz ka_roku.html.

Raubo, Agnieszka. 2012. „Antyczne źródła renesansowej teorii afektów”. Symbolae Philologorum Posnaniensium Graecae et Latinae XXII/1: $145^{-166 .}$

Sadkowska, Klara. b.d. „Melancholia - od alegorii Dürera do współczesnego symbolu”. Dostęp: 13.03.2020. https://www.academia.edu/36509884/ Klara_Sadkowska_Melancholia_-_od_alegorii_Durera_do_wsp\% 3 $\% \mathrm{~B} 3 \% \mathrm{C} 5 \% 82$ czesnego_symbolu.pdf.

Shusterman, Richard. 2012. „Pamięć mięśniowa i somaestetyczne patologie życia codziennego". [w:] Richard Shusterman Eseje z zakresu somaestetyki. Tłum. Patrycja Poniatowska, 121-144. Warszawa: Instytut Wydawniczy Książka i Prasa.

Skwara, Marta i Marek Skwara. 1997. „Melancholia - głupota - pycha szaleństwo: o motywach polskiej literatury XVII wieku”. Pamiętnik Literacki 88/3: 35-65.

Starobinski, Jean. 2017. „Historia leczenia melancholii”. [w:] Jean Starobinski, Atrament melancholii. Tłum. Krystyna Belaid, 15-114. Gdańsk: słowo/obraz terytoria. 
Szostak, Natalia. 2018. „Nagroda Bookera dla Olgi Tokarczuk”. Gazeta Wyborcza. Dostęp: 13.03.2020. https://wyborcza.pl/7,75517,23437938,olgatokarczuk-laureatka-miedzynarodowego-bookera-prestizowa.html.

Śniedziewski, Piotr. 2011. Melancholijne spojrzenie. Kraków: Universitas. Świeściak, Alina. 2010. Melancholia w poezji polskiej po 1989 roku. Kraków: Universitas.

Tokarczuk, Olga. 2007. Bieguni. Kraków: Wydawnictwo Literackie. 2008. „Jestem okiem i uchem”. Gazeta Wyborcza. Wywiad przeprowadziła Agnieszka Wolny-Hamkało. Dostęp: 13.03.2020. https://wyborcza. pl/1,75410,5698348,Jestem_okiem_i_uchem.html.

Wroniszewski, Maksymilian. 2015. „Spleen, nuda, melancholia: czytając Eugeniusza Oniegina". Prace Literaturoznawcze 3: 31-43. 


\title{
Abstract, keywords, about the author
}

\begin{abstract}
Melancholy as a loss experience. A literary case study based on the character of Olga Tokarczuk's „Flights”.

This article is a proposed reading of an extract from Olga Tokarczuk's book in the perspective of a melancholic experience and aims to show the melancholic trait of the selected character of the „Flights”. The author, using interpretation techniques from the field of literary studies, creates a kind of case study: she analyses the literary text and indicates the melancholy trails that appear in the whole artistic creation of the author of "The Books of Jacob”. The character of the Flemish scientist Filip Verheyen is examined in terms of human nature and the body, which 'responds' to mental suffering.
\end{abstract}

Keywords: melancholy, loss, pain, Tokarczuk, Flights

Karolina WycıśLıK, PhD candidate of Doctoral School of the University of Silesia in the field of literature studies, her research interests include contemporary prose and the links between music and literature - especially twentieth-century poetry - in the perspective of acoustic ecology.

E-MAIL: karolina.wycislik@us.edu.pl 